\title{
The function of the dewclaw in the Scandinavian red fox (Vulpes vulpes)
}

\begin{abstract}
Jan K. Å. Englund
ABSTRACT. In foxes, Vulpes vulpes, the dewclaw sits on the forelimb a bit up from the ground. It is usually thought to be functionless. The length of metacarpal 1 and metacarpal 3, as well as the relation between them (Mc1 / Mc3), increases northwards from Denmark to northern Sweden. If it were the same physiological system regulating the growth of all the metacarpal bones, they would increase at the same ratio and the long metacarpal $3(43-64 \mathrm{~mm})$ would therefore increase northwards in absolute length more than the shorter metacarpal $1(13-20 \mathrm{~mm})$. In this case the dewclaw in northern foxes would be set higher above the ground than in southern ones. If measured as a percentage, however, the mean length of metacarpal 1 shows a larger increase northwards than that of the other metacarpal bones. The tip of the nail of the dewclaw in foxes is shown to be $12-15 \mathrm{~mm}$ above the ground in all areas in Scandinavia, and the dewclaw is therefore considered to have an important function. It is believed to increase the effectiveness of hunting voles, when the dewclaws will hit the back of the prey.
\end{abstract}

How to cite this article: Englund J.K.A. 2020. The function of the dewclaw in the Scandinavian red fox (Vulpes vulpes) // Russian J. Theriol. Vol.19. No.2. P.172-177. doi: 10.15298/rusjtheriol.19.2.07.

KEY WORDS: anatomical adaptation, dewclaw, metacarpal, red fox, Vulpes vulpes.

Jan K. A. Englund [je.fox@swipnet.se],Kattfotsbacken 16, S-165 73 Hässelby,Sweden.

\section{О функции первого пальца передней конечности у скандинавской обыкновенной лисицы (Vulpes vulpes)}

\begin{abstract}
Я.К.О. Энглунд
РЕЗЮМЕ. У лисиц укороченный (рудиментарный) первый палец расположен на передней конечности выше остальных пальцев и не достает до земли. Принято считать, что он не несет функциональной нагрузки. Длина первой и третьей метакарпальных костей, как и величина отношения между ними (Mc1 / Mc3) возрастают в направлении от Дании к северной Швеции. Если бы рост всех метакарпальных костей регулировался одним и тем же физиологическим механизмом, то их абсолютная длина увеличивалась бы равно пропорционально, и длинная Мс3 (43-64 мм) удлинялась бы в северном направлении значительнее, чем более короткая Mc1 (13-20 мм). В этом случае первый палец у северных лисиц оказался бы расположенным выше над поверхностью земли, чем у южных. Если же выразить увеличение длины в процентах, то окажется, что средняя длина Мc1 возрастает к северу больше, чем длина других метакарпальных костей. Согласно полученным данным, конец когтя первого пальца находится на расстоянии 12-15 мм от поверхности земли у лисиц во всех областях Скандинавии. Вероятно, первый палец несет важную функциональную нагрузку и служит увеличению эффективности охоты на полевок, помогая удерживать добычу.
\end{abstract}

КЛЮЧЕВЫЕ СЛОВА: анатомическая адаптация, рудиментарный первый палец, метакарпалии, обыкновенная лисица, Vulpes vulpes.

\section{Introduction}

The dewclaw in the red fox Vulpes vulpes (Linnaeus, 1758) sits on the fore legs and high up from the ground, and its distal end does not make contact with the ground, when the animals are standing. It is often thought to be totally functionless. But in such a case, why is the dewclaw still left on the fore leg whereas the corresponding toe has disappeared at the hind leg? Dr. Chris Zink (pers. comm., 2019) at the John Hopkins University (USA) believes that the dewclaws are very important for dogs. As she says there are 5 tendons attached to the dewclaw and at the other end of the tendons there are muscles. When the dog is galloping the dewclaw, which then is in contact with the ground, will dig into the ground, which make it easier for the 
dog to change the direction. In this situation the muscles attached to the dewclaw will reduce the risk of twisting the fore legs.

\section{Material and methods}

The present paper is based mainly on data obtained from the author's private collection of foxes collected in Scandinavia in 2010-2018 and some few specimens from the author's collection at the Swedish Museum of Natural History in Stockholm.

Some foxes are from the coniferous belt in northern and southern Norrland (here called S1, 62-68 $\mathrm{N}$ latitude and $\mathrm{S} 2,59.5-62^{\circ} \mathrm{N}$; the southern part of Dalarna is included in southern Norrland). The agricultural habitats are represented by three areas, which are the central part of Sweden $\left(\mathrm{S} 3,58.5-60^{\circ} \mathrm{N}\right)$, the most southern province in Sweden called Scania (S4, 55.3-56.3 ${ }^{\circ} \mathrm{N}$; the southern part of Halland and Blekinge are included) and Denmark (Dk, $55-58^{\circ}$ N, Fig. 1).

Metacarpal 1 (Mc1) and metacarpal 3 (Mc3) were measured to the nearest $0.01 \mathrm{~mm}$. In juvenile specimens only those bones that were full grown according to the suture conditions in metacarpal 3 have been taken into account. The distance between the tips of the nails of the dewclaw and the second toe has been measured to the nearest $\mathrm{mm}$, the foot being straightened. Metacarpal 1 was measured according to as it is shown in Fig. 2.

To examine whether the foxes in the different groups differed in size, ANOVA tests followed by Hochberg's GT2 post hoc tests were carried out. Figures were drawn using the software package PIA (Bignert, 2013). The error bars in the figures specify the $95 \%$ confidence interval of the mean.

The significance of the differences in the means are shown by asterisks where $(* *)=p<0.02, * *=p<0.01$ and $* * *=p<0.001$. Differences in measurements were considered significant when $p<0.02$. The number of specimens is given below the shortenings of the areas studied.

\section{Results}

Except for the very large foxes in Scania (S4), metacarpal 1 and metacarpal 3 show continual increase in length northwards from Denmark to northern Sweden (Fig. 3) and Appendices 1, 2).

The quotient between the lengths of metacarpal 1 and metacarpal 3 increases northwards as well (Fig. 4). This means that the percentage increase of the length of metacarpal 1 is larger than that of metacarpal 3.

Except for the large foxes in Scania, the distance between the tips of the nails of the dewclaw and the second toe increases continually from Denmark to northern Norrland (Fig. 5, Appendix 3). In spite of that the tip of the nail of the dewclaw will be set at practically the same distance above the ground in all the areas studied (Appendix 4).

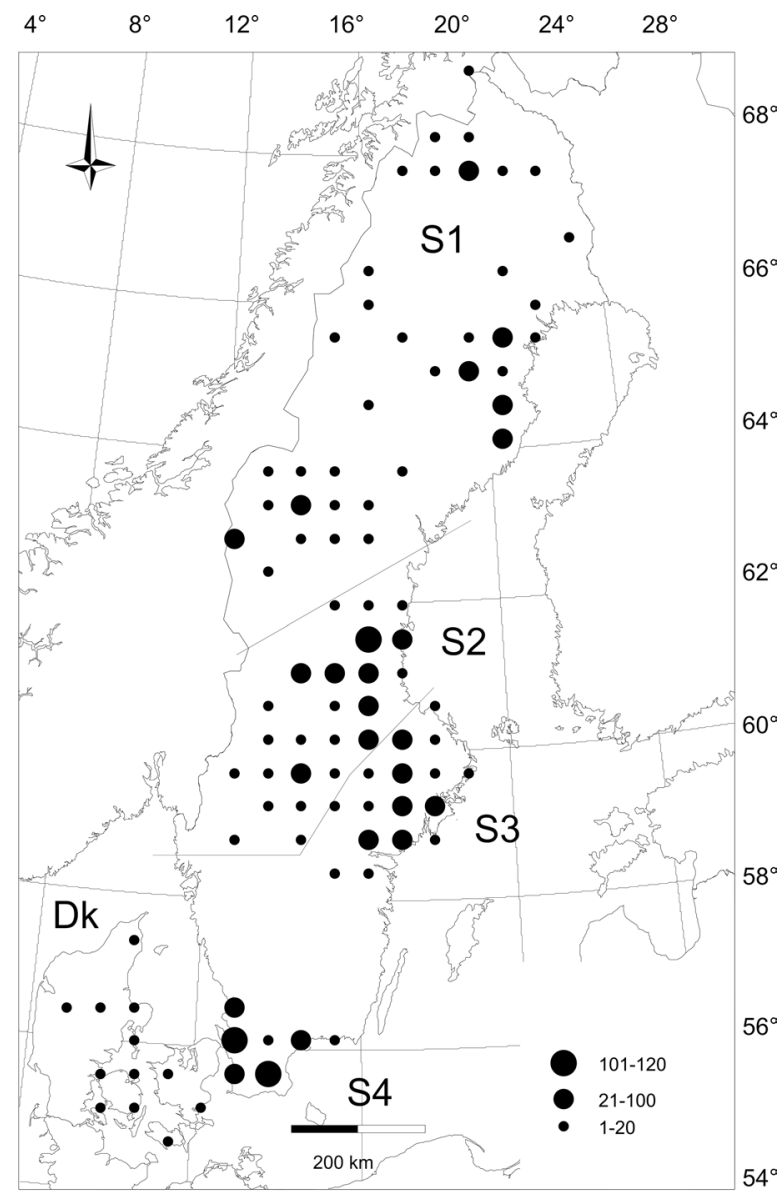

Fig. 1. The distribution of the material per $50 \times 50 \mathrm{~km}$ squares within five areas in Scandinavia (S1 - northern Norrland, S2 - southern Norrland, S3 - central Sweden, S4 - Scania, Dk - Denmark). Size of black circles shows the number of fox specimens studied.

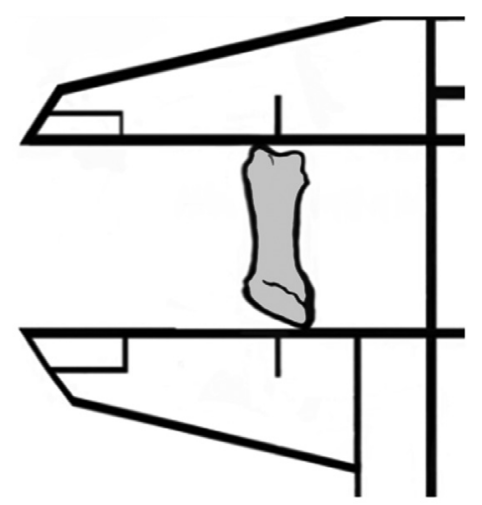

Fig. 2. When measuring the length of metacarpal 1 the two markings on the device are placed above the middle of the score and the sloping part at the opposite end of the bone. 

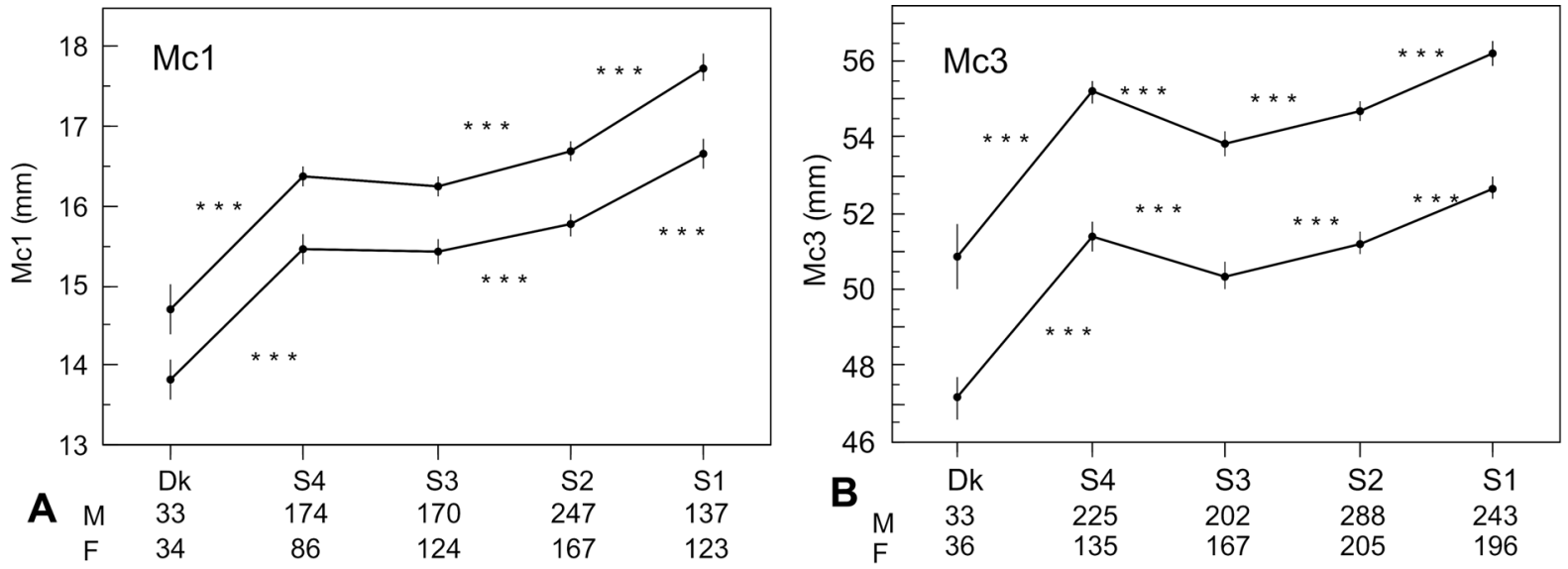

Fig. 3. Mean length of metacarpal 1 (A) and metacarpal 3 (B) in Scandinavian red foxes.
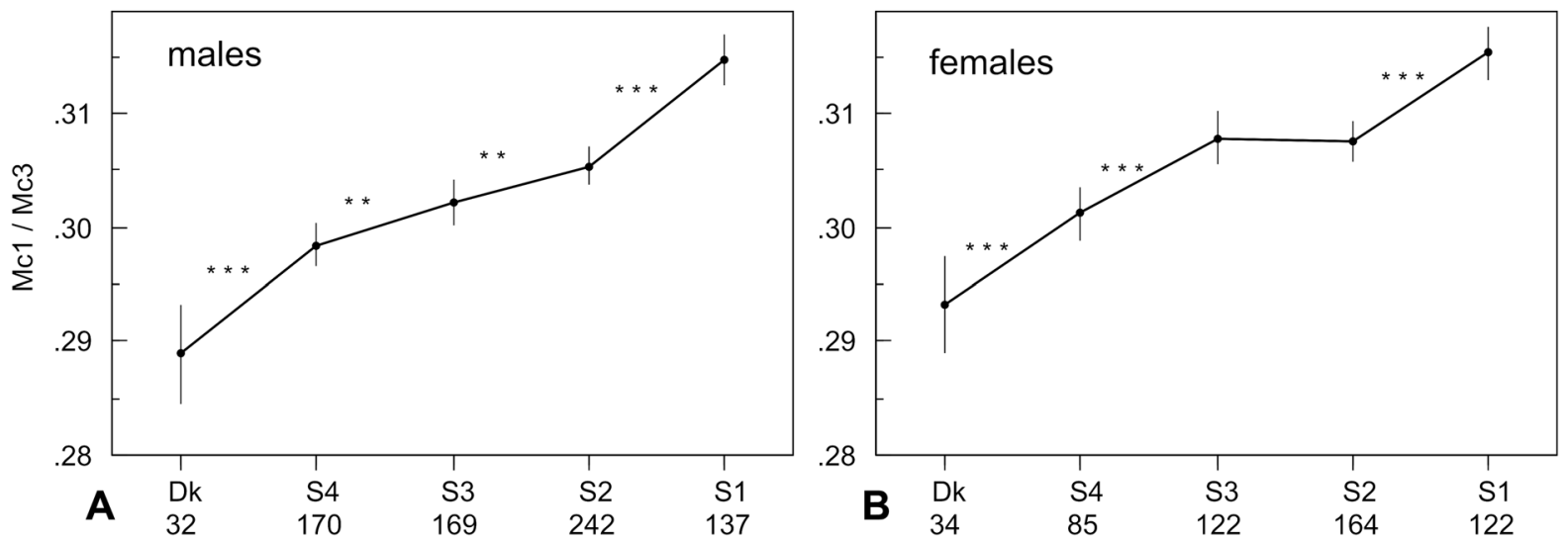

Fig. 4. The mean of the ratio between the lengths of metacarpal 1 and metacarpal 3 (Mc1 / Mc3) in Scandinavian red foxes.

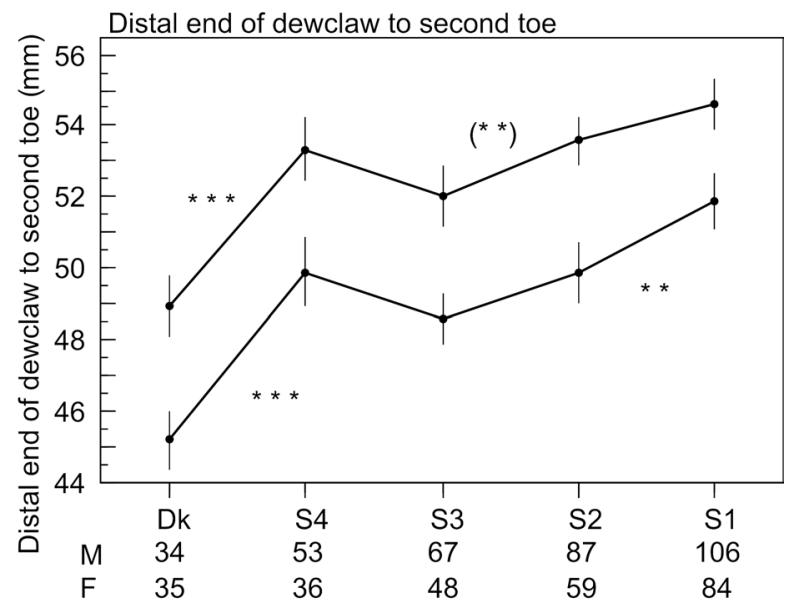

Fig. 5. The mean distance $(\mathrm{mm})$ between the tips of the nails of the dewclaw and the second toe in Scandinavian red fox. 


\section{Discussion}

The dewclaw is set high up from the ground in the fore legs and therefore its claw will not reach down to the ground. This digit is considered by many to be an ancient relic, which completely lacks any value. Dr. Zink (pers. comm., 2019), however, argues that the dewclaw is vital, since the muscles attached to metacarpal 1 will decrease the risk for twisting the leg. This is a strong argument showing that the dewclaw and metacarpal 1 are vital but there is no argument as to why the dewclaw will sit above the ground level.

Apart from the foxes in Scania, which have very long legs because the foxes there are very large (unpublished data) the legs show a continuous increase in length northwards as an adaptation to the larger amount of snow (unpublished data). Since metacarpals 2-5 are an extension of the fore legs these bones also increase in length northwards (Fig. 3). If it were the same physiological system that had caused the lengthening of all the five metacarpals, the length of all the bones would increase with the same percentage. The mean length of metacarpal 3 varies between 47 and $56 \mathrm{~mm}$ whereas the mean length of metacarpal 1 varies between 14 and $18 \mathrm{~mm}$ (Fig. 3 and Appendices 1,2), both increasing northwards. In such a case the absolute length of metacarpal 3 should show a larger increase than that of metacarpal 1 and the distal end of the dewclaw would therefore be higher above the ground in the northern foxes.

However, metacarpal 1 increases more in per cent than metacarpal 3 (Fig. 4), which means that the distal end of the dewclaw in the northern foxes is in fact closer to the ground than it otherwise should have been. Thus the dewclaw must have some function to perform that has to do with the distance to the ground.

The mean distance between the tips of the nails of the dewclaw and the second toe increases about six mm from Denmark to northern Norrland (Fig. 5, Appendix 3). Since foxes walk on their digits and not on the distal tips of them, the distance between the tip of the nail of the dewclaw and the ground is equal to the distance between the tips of the nails of the dewclaw and the second toe (stretched) minus the total length of all digits of the second toe (which approximately is about twice the length of the proximal phalange of the second toe). Since the toes are longer in the northern foxes (unpublished data) the distal end of the nail of the dewclaw is at about the same level above the ground in foxes from all areas in
Scandinavia, a mean value varying from 14 to $15 \mathrm{~mm}$ in males and 12 to $13 \mathrm{~mm}$ in females (Appendix 4).

When foxes are hunting voles (a technique known as mousing) they leap into the air and strike their prey from above. The chance to catch the vole will obviously increase if the tips of the nails of the dewclaw hit the back of the vole, especially if the prey had moved a little while the fox is up in the air.

Thus, the possible function of the dewclaw is to make the mousing more effective. However, to have a correct length of metacarpal 1 so the hunting of voles will be more successful seems not to be as important as to have the appropriate length of the legs, since metacarpal 3 has a lower variation (SD) than metacarpal 1 in ten times out of ten and with $p<0.01$ in seven of the comparisons (Appendix 5).

The suggestion that the dewclaw will make the vole hunting more effective can be verified or questioned by examining the skins from voles captured by foxes.

ACKNOWLEDGEMENTS. I wish to express my appreciation to all hunters who have made this investigation possible by delivering all the foxes. I am also very grateful to Dr. M. Elmeros at the Game Biology Station at Kalø in Denmark, who supplied me with all the Danish foxes and made it possible for me to work at the Station. Furthermore I will thank the local hunter organizations in northern Sweden and the Journal for Swedish Sportsmen Association for their economic support. I am also very grateful to Professor T. Willebrand at the Hedmark University of Applied Sciences in Norway and Assistant Professor G. Samelius at the Swedish University of Agricultural Sciences (SLU) in Sweden for their economic support during several years. Without the help from all these people it had not been possible to collect the foxes needed for the present investigation. I will also thank my wife Galina, who helped me to slaughter the foxes and clean the skeleton parts, Eva Englund for the drawing of figure 2 and Professor A. Bignert for the statistical tests and for producing the diagrams.

\section{References}

Bignert A. 2013. The PIA Application for Statistical Analysis of Time-series Data. Available from http://www.amap.no/ documents/. 
Appendix 1. Mean length of metacarpal $1(\mathrm{~mm})$. Diff $=$ difference.

\begin{tabular}{|c|c|c|c|c|c|c|c|c|c|c|}
\hline & \multicolumn{5}{|c|}{ Males } & \multicolumn{5}{|c|}{ Females } \\
\hline Region & $\mathrm{Dk}$ & $\mathrm{S} 4$ & S3 & $\mathrm{S} 2$ & $\mathrm{~S} 1$ & $\mathrm{Dk}$ & S4 & S3 & $\mathrm{S} 2$ & $\mathrm{~S} 1$ \\
\hline Mean & 14.7 & 16.4 & 16.2 & 16.7 & 17.7 & 13.8 & 15.4 & 15.4 & 15.8 & 16.7 \\
\hline SD & 0.892 & 0.896 & 0.860 & 0.938 & 1.080 & 0.689 & 0.890 & 0.851 & 0.912 & 0.991 \\
\hline$n$ & 33 & 174 & 170 & 247 & 137 & 34 & 86 & 124 & 167 & 123 \\
\hline Median & 14.7 & 16.2 & 16.3 & 16.6 & 17.8 & 13.6 & 15.4 & 15.4 & 15.8 & 16.7 \\
\hline Max & 16.5 & 19.2 & 18.3 & 19.6 & 20.0 & 15.7 & 19.1 & 17.9 & 18.9 & 19.5 \\
\hline Min & 13.2 & 14.6 & 13.6 & 14.6 & 14.9 & 12.6 & 13.7 & 13.7 & 13.6 & 14.0 \\
\hline & \multicolumn{2}{|c|}{ Dk-S4 } & S4-S3 & S3-S2 & S2-S1 & \multicolumn{2}{|c|}{ Dk-S4 } & S4-S3 & S3-S2 & $\mathrm{S} 2-\mathrm{S} 1$ \\
\hline Diff, $\mathrm{mm}$ & \multicolumn{2}{|c|}{1.7} & -0.1 & 0.4 & 1.1 & \multicolumn{2}{|c|}{1.6} & 0.0 & 0.3 & 0.9 \\
\hline Diff, $\%$ & \multicolumn{2}{|c|}{11.3} & -0.8 & 2.7 & 6.3 & \multicolumn{2}{|c|}{11.8} & -0.2 & 2.2 & 5.7 \\
\hline$p<$ & \multicolumn{2}{|c|}{0.001} & & 0.001 & 0.001 & \multicolumn{2}{|c|}{0.001} & & 0.001 & 0.001 \\
\hline
\end{tabular}

Appendix 2. Mean length of metacarpal $3(\mathrm{~mm})$. Diff $=$ difference.

\begin{tabular}{|c|c|c|c|c|c|c|c|c|c|c|}
\hline & \multicolumn{5}{|c|}{ Males } & \multicolumn{5}{|c|}{ Females } \\
\hline Region & $\mathrm{Dk}$ & S4 & S3 & S2 & $\mathrm{S} 1$ & $\mathrm{Dk}$ & S4 & S3 & $\mathrm{S} 2$ & $\mathrm{~S} 1$ \\
\hline Mean & 50.8 & 55.2 & 53.8 & 54.7 & 56.2 & 47.1 & 51.4 & 50.4 & 51.2 & 52.7 \\
\hline SD & 2.419 & 2.362 & 2.287 & 2.426 & 2.665 & 1.694 & 2.290 & 2.251 & 2.256 & 2.147 \\
\hline$n$ & 33 & 225 & 202 & 288 & 243 & 36 & 135 & 167 & 205 & 196 \\
\hline Median & 50.9 & 55.3 & 53.8 & 54.8 & 56.1 & 47.2 & 51.5 & 50.3 & 51.2 & 52.7 \\
\hline Max & 58.7 & 61.4 & 59.9 & 61.4 & 64.0 & 50.8 & 60.4 & 56.5 & 57.2 & 58.1 \\
\hline Min & 45.6 & 48.1 & 48.6 & 47.4 & 49.3 & 43.3 & 44.7 & 45.0 & 42.7 & 47.6 \\
\hline & \multicolumn{2}{|c|}{ Dk-S4 } & S4-S3 & S3-S2 & S2-S1 & \multicolumn{2}{|c|}{ Dk-S4 } & S4-S3 & S3-S2 & $\mathrm{S} 2-\mathrm{S} 1$ \\
\hline Diff, $\mathrm{mm}$ & \multicolumn{2}{|c|}{4.3} & -1.4 & 0.9 & 1.5 & \multicolumn{2}{|c|}{4.2} & -1.0 & 0.9 & 1.4 \\
\hline Diff, $\%$ & \multicolumn{2}{|c|}{8.6} & -2.5 & 1.6 & 2.8 & \multicolumn{2}{|c|}{9.0} & -2.0 & 1.7 & 2.8 \\
\hline$p<$ & \multicolumn{2}{|c|}{0.001} & 0.001 & 0.001 & 0.001 & \multicolumn{2}{|c|}{0.001} & 0.001 & 0.001 & 0.001 \\
\hline
\end{tabular}

Appendix 3. The distance between the tips of the nails of the dewclaw and the second toe $(\mathrm{mm})$. Diff $=$ difference.

\begin{tabular}{|c|c|c|c|c|c|c|c|c|c|c|}
\hline & \multicolumn{5}{|c|}{ Males } & \multicolumn{5}{|c|}{ Females } \\
\hline Regions & $\mathrm{Dk}$ & S4 & S3 & $\mathrm{S} 2$ & $\mathrm{~S} 1$ & $\mathrm{Dk}$ & S4 & S3 & $\mathrm{S} 2$ & S1 \\
\hline Mean & 49.0 & 53.3 & 52.0 & 53.6 & 54.6 & 45.2 & 49.9 & 48.6 & 49.8 & 51.9 \\
\hline SD & 2.407 & 3.174 & 3.505 & 3.172 & 3.776 & 2.400 & 2.816 & 2.507 & 3.251 & 3.690 \\
\hline$n$ & 34 & 53 & 67 & 87 & 106 & 35 & 36 & 48 & 59 & 84 \\
\hline Median & 49 & 53 & 52 & 54 & 54 & 46 & 50 & 49 & 49 & 52 \\
\hline Max & 54 & 62 & 60 & 63 & 65 & 50 & 59 & 55 & 59 & 61 \\
\hline Min & 45 & 46 & 44 & 43 & 45 & 40 & 44 & 42 & 44 & 44 \\
\hline & \multicolumn{2}{|c|}{ Dk-S4 } & S4-S3 & S3-S2 & $\mathrm{S} 2-\mathrm{S} 1$ & \multicolumn{2}{|c|}{ Dk-S4 } & S4-S3 & S3-S2 & $\mathrm{S} 2-\mathrm{S} 1$ \\
\hline Diff, $\mathrm{mm}$ & \multicolumn{2}{|c|}{4.3} & -1.3 & 1.6 & 1.0 & \multicolumn{2}{|c|}{4.7} & -1.3 & 1.2 & 2.1 \\
\hline Diff, \% & \multicolumn{2}{|c|}{8.8} & -2.4 & 3.1 & 1.9 & \multicolumn{2}{|c|}{10.4} & -2.6 & 2.5 & 4.2 \\
\hline
\end{tabular}


Appendix 4. The distance between the tip of the nail of the dewclaw and the ground (mm).

\begin{tabular}{|l|c|c|c|c|c|c|c|c|c|c|}
\hline & \multicolumn{4}{|c|}{ Males } & \multicolumn{5}{c|}{ Females } \\
\hline Regions & Dk & S4 & S3 & S2 & S1 & Dk & S4 & S3 & S2 & S1 \\
\hline Mean & 14 & 15 & 14 & 15 & 14 & 13 & 13 & 12 & 13 & 13 \\
\hline SD & 2.142 & 2.582 & 3.091 & 2.880 & 3.186 & 2.104 & 2.221 & 2.213 & 2.417 & 2.980 \\
\hline$n$ & 34 & 53 & 67 & 87 & 103 & 34 & 35 & 47 & 59 & 83 \\
\hline Median & 14 & 14 & 14 & 15 & 13 & 13 & 13 & 12 & 13 & 14 \\
\hline Max & 19 & 22 & 20 & 24 & 23 & 17 & 18 & 18 & 20 & 19 \\
\hline Min & 10 & 11 & 4 & 5 & 5 & 8 & 8 & 6 & 8 & 5 \\
\hline
\end{tabular}

Appendix 5. The standard deviation (SD) of normalised data of the length of metacarpal 1 (Mc1) and metacarpal 3 (Mc3) and the proportion of the (SD) $)^{2}$ for Mc1 (SD1) and Mc3 (SD3).

\begin{tabular}{|l|c|c|c|c|c|c|c|c|c|c|}
\hline & \multicolumn{4}{|c|}{ Males } & \multicolumn{5}{c|}{ Females } \\
\hline Regions & Dk & S4 & S3 & S2 & S1 & Dk & S4 & S3 & S2 & S1 \\
\hline SD, Mc1 & 0.059 & 0.055 & 0.053 & 0.056 & 0.061 & 0.050 & 0.058 & 0.054 & 0.058 & 0.059 \\
\hline SD, Mc3 & 0.047 & 0.044 & 0.041 & 0.043 & 0.047 & 0.036 & 0.046 & 0.041 & 0.042 & 0.042 \\
\hline$n$ & 32 & 169 & 169 & 242 & 137 & 34 & 85 & 121 & 164 & 121 \\
\hline$(\mathrm{SD} 1)^{2} /(\mathrm{SD} 3)^{2}$ & 1.546 & 1.567 & 1.651 & 1.678 & 1.674 & 1.894 & 1.550 & 1.762 & 1.898 & 2.021 \\
\hline$p<$ & - & 0.01 & 0.01 & 0.0001 & 0.01 & - & 0.05 & 0.01 & 0.0001 & 0.001 \\
\hline
\end{tabular}

